\title{
MEMAHAMI KREATIFITAS IKLAN
}

\author{
Noor Udin \\ Jurusan Desain Komunikasi Visual, Fakultas Komunikasi dan Multimedia, \\ Bina Nusantara University, Jln. K.H. Syahdan No 9, Palmerah, Jakarta Barat 11480 \\ noorudinung@yahoo.com
}

\begin{abstract}
Ads always exist in our midst, apparently was never fail to greet, inform and persuade us. Conscious or not, advertising has become an unavoidable part our lives from when we wake up until we sleep. This paper explores how advertising works and how it is able to hold their positions in the hearts of consumers or its target audience. The important thing that must be observed in the ad is the message in it. Messages should be delivered in an as simple as possible way so that the target audience is not biased by dualities in the message. The common understanding is the measure of success that is associated with the after sale just the same as another type of capital investment. This understanding affects advertisers to create simple and rudimentary ads. The desire to enjoy and see pretty, intelligent and communicative advertisements must be born from the campus. The advertisements are not just created to represent the intent of advertisers, but also to carry moral and educational variables for the audience.
\end{abstract}

Keyword: advertisement, target audience, communicative advertisement

\begin{abstract}
ABSTRAK
Iklan selalu ada di tengah-tengah kita, rupanya tak pernah istirahat untuk menyapa, mengabarkan dan membujuk kita. Sadar atau tidak, iklan telah menjadi bagian tak terpisahkan dari sendi-sendi kehidupan kita dari mata terbuka hingga tertutup kembali.Untuk itu di dalam tulisan ini mengupas bagaimana iklan bekerja dan bagaimana dia mampu bertahan menduduki posisinya di hati konsumen atau target audience-nya. Yang harus dicermati di dalam iklan adalah pesan yang ada di dalamnya. Pesan harus dibawa dengan sesimple mungkin sehingga sasaran pemirsa tidak dibiaskan oleh pesan yang mempunyai makna ganda. Pemahaman yang sering kali muncul adalah ukuran kesuksesan penjualan setelah yang dikaitkan dengan modal yang dipakai untuk produksi. Pemahaman ini yang mempengaruhi pengiklan untuk membuat iklan hanya sekedarnya. Keinginan untuk bisa menikmati dan melihat iklan-iklan cantik, cerdas dan komunikatif tentu saja harus lahir dari kampus. Iklan bukan hanya diciptakan untuk mewakili hajat pengiklan saja namun juga harus bisa mengusung variabel moral dan pendidikan bagi penikmatnya.
\end{abstract}

Kata kunci: iklan, sasaran pemirsa, iklan komunikatif 


\section{PENDAHULUAN}

Iklan yang selalu kita ada di tengah-tengah kita, rupanya tak pernah istirahat untuk menyapa, mengabarkan dan membujuk kita. Iklan tak pernah capek nongol di sela-sela kehidupan kita dimanapun kita berada. Kelaziman yang menjadi tempat iklan itu muncul bahkan di tempat yang asing yang sama sekali jauh dari kelaziman dari iklan itu sendiri. Tiba-tiba muncul di beberapa tahun ke belakang, higar-bingarnya iklan di perbagai tempat. Sebuah kawasan lapak kaki lima yang biasa menjajakan aneka makanan, sering kali kita temui iklan iklan-iklan minuman ringan atau teh botol, atau produk-produk yang berhubungan dengan makanan atau minuman. Namun, di kawasan seperti ini justru disesaki oleh iklan-iklan operator ponsel, pastilah orang yang baru mengenal kawasan tersebut akan terkecoh dengan kawasan itu.

Iklan mempunyai cara tersendiri untuk selalu mengikuti targetnya kemana pun. Iklan menyelinap bak temen yang sangat pribadi di ponsel, di kamar mandi, di kamar dan tempat-tempat pribadi lainnya. Iklan bahkan menjadi begitu otomatis saat target audience-nya bangga dengan variabel pada iklan tersebut yang tidak lain adalah produk itu sendiri. Iklan juga menyuntikkan pengaruh kepemilikan yang begitu emosional; merek dan label, misalnya. Kekuatan ini mengalahkan etalase yang lengkap dan megah sekali pun. Sadar atau tidak, iklan telah menjadi bagian tak terpisahkan dari sendi-sendi kehidupan kita dari mata terbuka hingga tertutup kembali.

Untuk itu di dalam tulisan ini mengupas bagaimana iklan bekerja dan bagaimana dia mampu bertahan menduduki posisinya di hati konsumen atau target audience-nya. Tulisan ini dianggap sangat penting dalam memberikan bobot apresiasi sekali gus mengkritisi kiprah iklan yang jelas memeiliki dimensi ekonomi, sosial, politik dan moral kita. Dengan demikina dapat kita siapkan iklan-iklan yang bukan hanya diciptakan untuk kebutuhan klasik penjualan namun juga memiliki makna cakupan yang lebih luas.

\section{Sekilas tentang Pengertian dan Tujuan Iklan}

Iklan didefinisikan dalam berbagai konteks dan pemahaman. Menurut Tom Duncan (2005) di Advertising \& IMC, "It is used to reach large audiences, create brand awareness, help differentiate a brand from its competitors, and build an image of the brand." Definisi membawa pemahaman bahwa iklan berperan sangat baik terhadap brand positioning dengan target audience maupun target marketnya. Bahwa iklan merupakan cara untuk membedakan dengan produk competitor, dan sarana untuk membangun pencitraan.

Lain lagi dengan definisi yang dituliskan oleh Institut Praktisi Periklanan Inggris, bahwa iklan memiliki arti sebagai pesan-pesan penjualan yang paling persuasif yang diarahkan kepada calon pembeli yang paling potensial atas produk barang atau jasa tertentu dengan biaya tertentu (biaya media). Pembahasan ini mengukuhkan iklan sebagai cara yang sangat focus dimana sudah ditentukan pesannya yang sangat khusus, untuk calon pembeli yang sudah ditentukan potensinya untuk melakukan pembayaran, dalam situasi dan penetapan jenis media yang juga sudah dipilih atau ditentukan. Sehingga iklan merupakan strategi yang sudah sangat fokus dalam membidik sasarannya. Dalam penegrtian yang ke dua ini tentu saja dalam memunculkan iklan harus melalui beberapa tahapan yang sangat kompleks, di antaranya tahap riset, tahap, analisa, tahap brainstorming, tahap produksi dan tahap perencanaan media. Sudah bisa dibayangkan bahwa iklan yang akan dihasilkan menurut pemahaman ini bukanlah iklan yang asal tayang namun iklan yang memiliki kekuatan yang bisa dipertanggung jawabkan. Selain dua definisi iklan di atas, tentulah masih banyak lagi yang lain. Apa lagi perkembangan iklan sangat creative oriented yang merupakan faktor utama penggerak iklan iklan itu sendiri, karena sifat dasar sebuah iklan adalah kretifitas yang menyelesaikan masalah. 


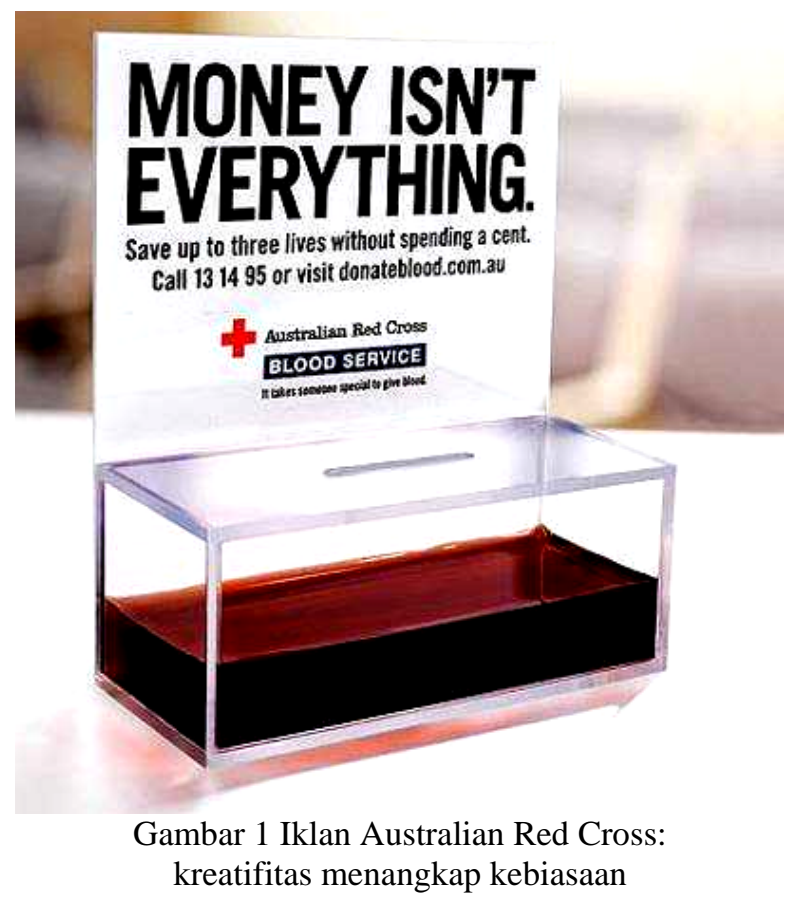

PEMBAHASAN

\section{Iklan Bagian Spesial dalam Marketing}

Dalam kaidah pemasaran klasik iklan merupakan bagian kecil dari proses pemasaran, ada di bauran promotion mix, tentu saja iklan memiliki peran yang sama penting dengan beberapa unsur lainnya. Namun, iklan menjadi ajaib sejak dilahirkan. Iklan dipuja, dihujat namun juga dibutuhkan secara mutlak. Bahkan iklan terkadang hadir sendirian tanpa ditemani saudara-saudara kandungnya. Iklan membentuk gen pribadinya, melalui media yang mengusungnya. Sifatnya yang berteriak, bombabastis, dramatis dan menggoda, iklan me-make-up dirinya sehingga banyak yang sengsem melihatnya. Maka banyak pihak yang rela merogoh koceknya melebihi separo bahkan lebih dari biaya produksi untuk membayar iklan.

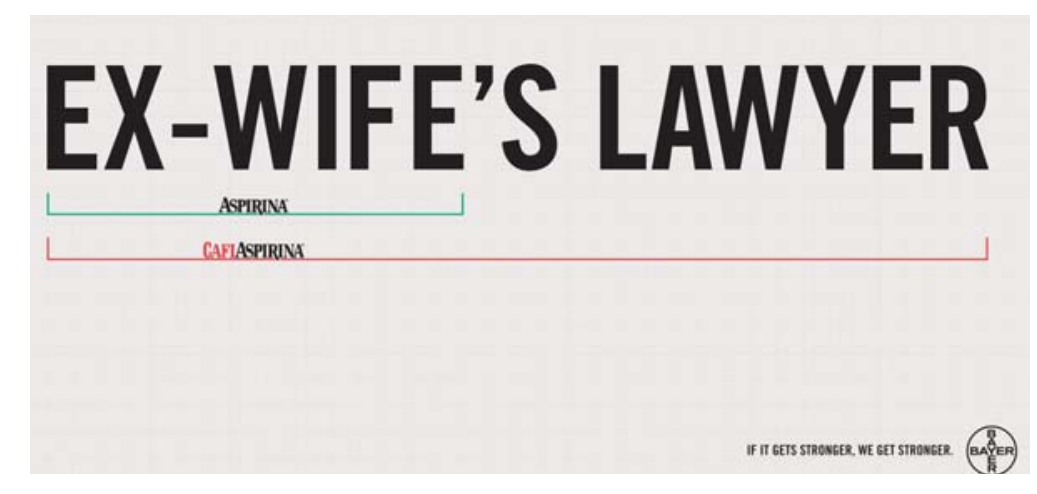

Gambar 2 Iklan Cafi Aspirina: Melepas bahasa marketing 


\section{Pendekatan Komunikasi dalam Iklan}

Komunikasi iklan benar-benar berbeda dengan model komunikasi lain. Dia tampil lebih unik, bebas sesuai dengan perkembangan media, bahkan terkadang terselubung. Pada akhirnya, siapapun akan secara otomatis tak sadarkan diri bahwa mereka adalah iklan yang dijadikan iklan oleh iklan (ads on ads). Artinya, iklan akan menginjeksi manusia menjadi iklan-iklan yang benar-benar hidup. Bergaya dan bertingkah laku menggayakan dan merefleksikan iklan. Semua orang akan mengambil kesepakatan makro bahwa nilai-nilai sosial budaya adalah produk dari iklan. Iklan juga semakin sulit diidentifikasi karena wujudnya akan semakin abstrak dan intangible.

Sebagai contoh iklan rokok, yang karena peraturannya sangat ketat, mereka akhirnya bersimbiosis dengan kaidah-kaidah moral dan sosial bahkan meminjam situasi politik untuk bicara. Ada juga yang akhirnya beradaptasi dengan cara yang nyaris sama sekali tidak ada hubungannya dengan produk atau pun pesan dari iklannya. Berikut adalah beberapa penedekatan komunikasi dalam iklan.

\section{Spokesperson}

Seseorang akan tampil untuk menyampaikan pesan sebagai 'presenter' atau dikenal juga dengan sebutan Endorser. Dalam pemilihan presenter, haruslah seseorang yang mempunyai kepribadian yang dapat disukai atau dapat dipercaya oleh target audience. Misalnya Adi Bing Slamet pada jaman emasnya.

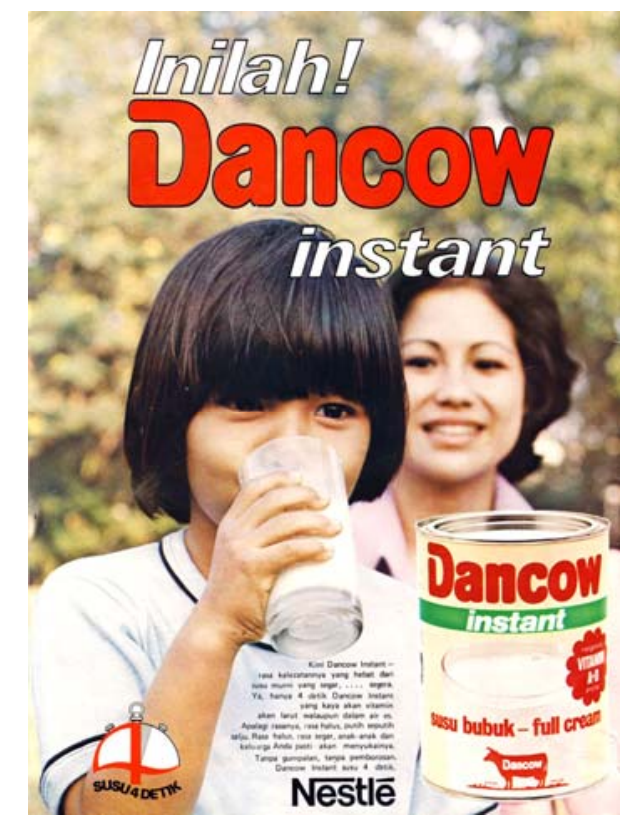

Gambar 3 Iklan Dancow: Memakai figure Selebritis

\section{Testimonial}

Biasanya cara pemakaian testimonial ini dilakukan oleh seseorang yang mempunyai kaitan langsung dengan brand yang kita iklankan (pemakai produk). Sebaiknya orang yang dipakai juga dapat mempengaruhi pembaca/pemirsa, mereka bisa orang terkenal atau orang biasa, yang penting target audience bisa menerima dan percaya si 'endoser'. 


\section{Direction/demonstration}

Pendekatan ini dipakai untuk produk yang membutuhkan cara menggunakan, atau mengarahkan target audience untuk melakukan seperti yang diinginkan pengiklan.

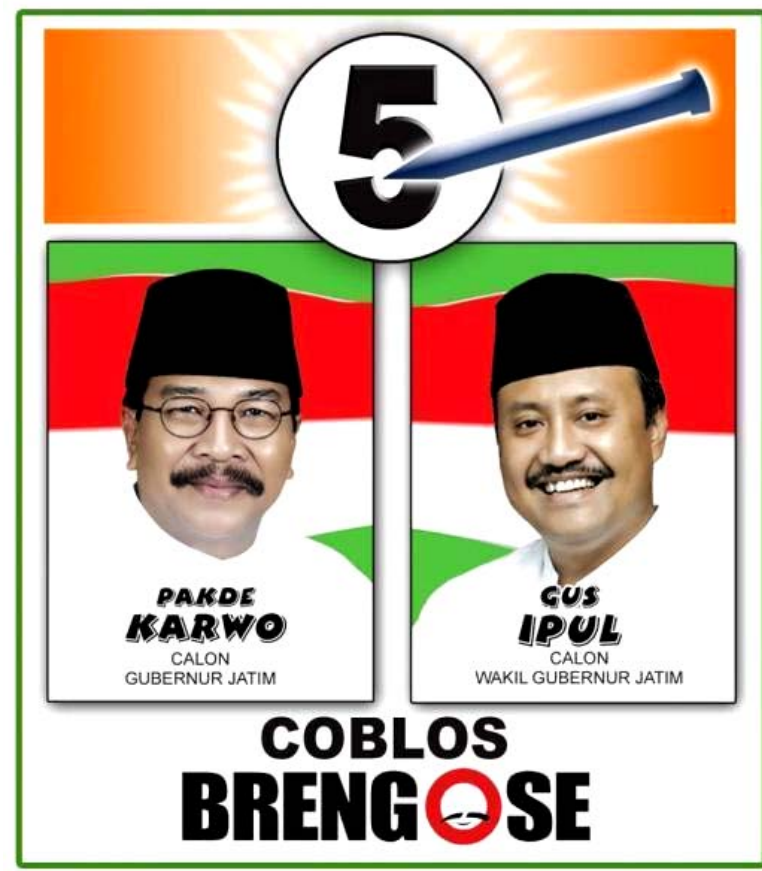

Gambar 4 Iklan Pilkada Jatim: Memanfaatkan iklan untuk mengarahkan calon pemilih

Iklan ini juga biasa kita jumpai pada produk-produk rumah tangga sepeti sabun bubuk. Contohnya, Surf dan Sunlight.

\section{Slice of life}

Cara ini banyak dipakai berdasarkan dramatisasi dari problem-solution dengan memakai halhal biasa yang terjadi dalam keseharian kita. Iklan ini sering sekali dijumpai pada iklan layanaan masyarakat yang ditayangkan oleh pemerintah, misalnya kampanye aman Elpiji 3kg.

\section{Story telling}

Penyampaian pesan yang dikemas dalam satu cerita. kebanyakan teknik ini dipergunakan untuk iklan televisi. Pendekatannya bisa dengan dramatisasi keseharian atau slice of life. Misalnya, iklan serial atau film pendek Pond's.

\section{Metaphor \& Analogi}

Pendekatan ini biasanya ini dilakukan apabila kita harus menyampaikan satu performa yang sulit untuk diperlihatkan secara langsung. Misalnya, mobil yang cepat dianalogikan dengan kuda, iklan rokok, iklan obat kuat lelaki. 


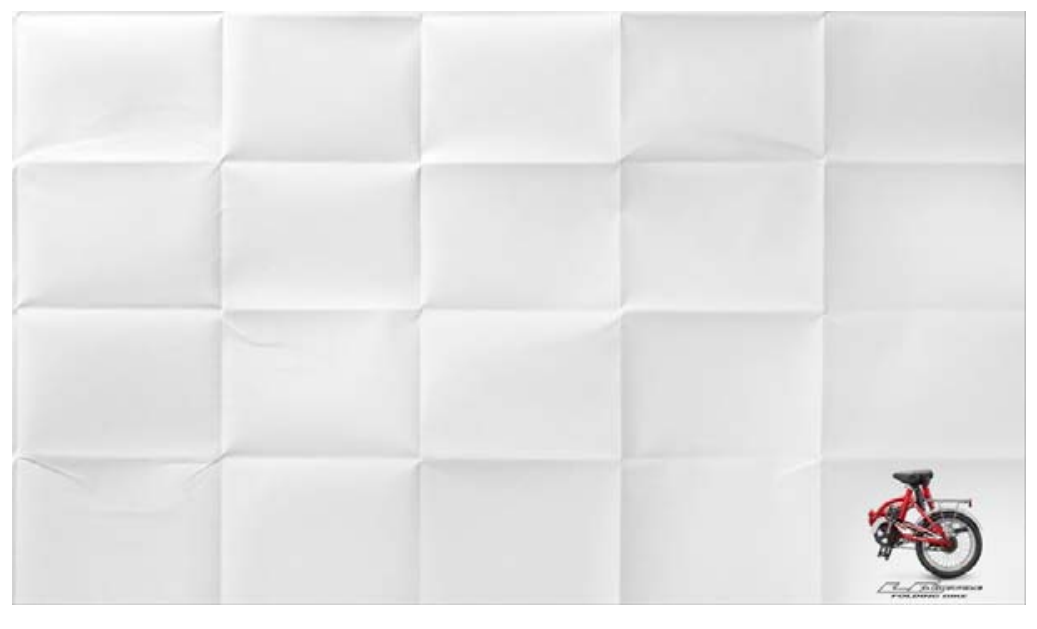

Gambar 5 Iklan Sepeda Lipat: Mencari padanan visual mewakili benefitnya

\section{Problem $><$ Solution}

Pendekatan yang paling banyak dipakai dalam iklan, pendekatan ini biasanya menampilkan dua elemen yaitu masalah dan solusinya. Produk sangat berperan untuk mengkomunikasikan pesan sebagai solusi.

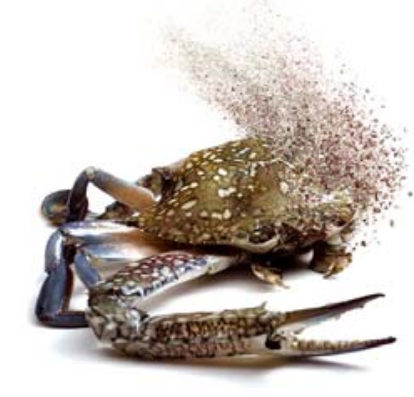

Gambar 6 Iklan Ambi Pur: No Copy ad,

Pendekatan visual yang cerdas

\section{Hal-Hal yang Melemahkan Posisi Iklan karena Lemahnya Kreatifitas Iklan Iklan Promo Jebakan}

Yang harus dicermati di dalam iklan adalah pesan yang ada di dalamnya. Pesan harus dibawa dengan sesimple mungkin sehingga target audience tidak dibiaskan oleh pesan yang bersayap. Banyak kita jumpai pada iklan-iklan promo yang menawarkan produk secara taktis. Pada kebanyakan iklan tersebut selalu menyertakan persyaratan yang tersembunyi, iklan dipakai hanya untuk stopping power saja. Iklan seperti ini tentunya sangat tidak berfungsi maksimal, target audience akan mengambil langkah yang hati hati bahkan akan menghindari iklan ini. 


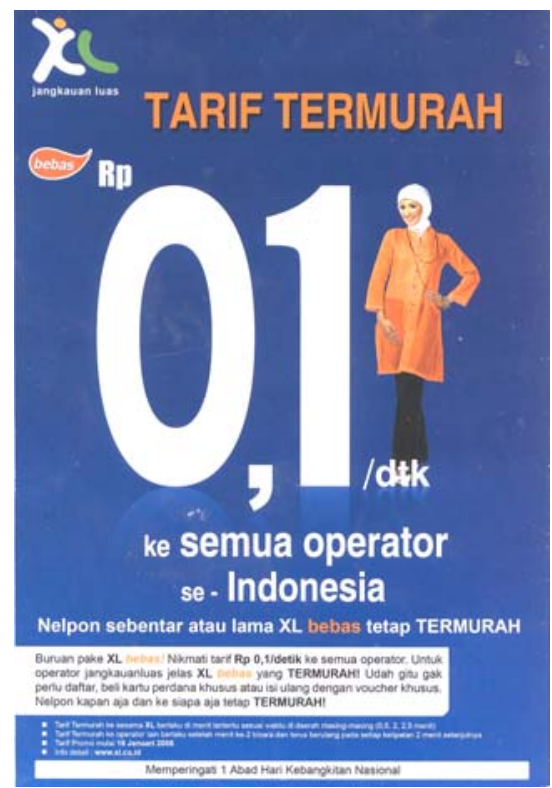

Gambar 7 Iklan Promo:

Banyak pesan elum tersampaikan.

Iklan-iklan yang menggunakan pendekatan spektakular ini biasanya iklan-iklan untuk produk yang head to head, misalnya jor-joran diskon super market, operator ponsel. Iklan promo sudah selayaknya dipikirkan sematang mungkin agar tercipta iklan-iklan promo yang mempunyai daya magis kreatif yang tinggi seperti iklan-iklan tematik. Memang masih sulit sekali menemukan iklan promo yang mampu menampilkan kreatifitas visual dan teks yang hebat.

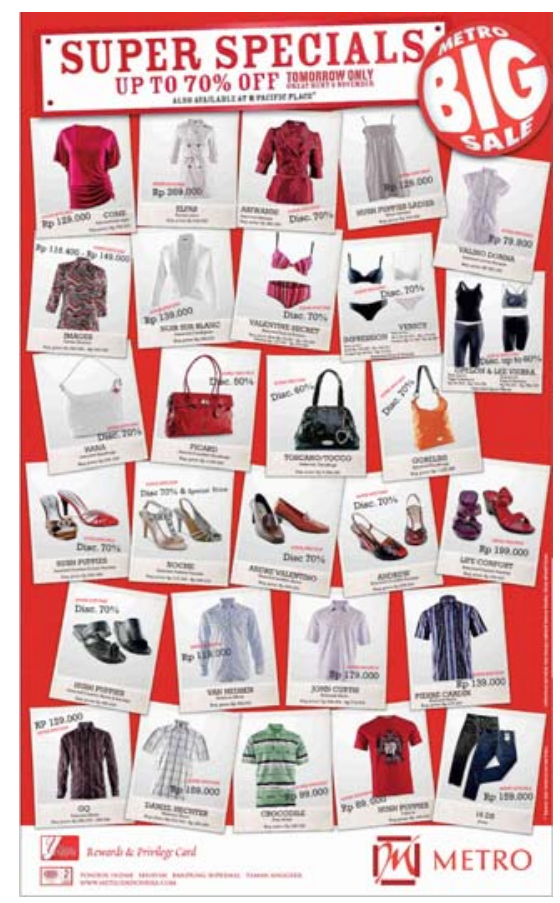

Gambar 8 Iklan Promo: Tipis sekali Perbedaannya dengan Iklan-iklan Promo lainnya 


\section{Iklan Tanpa Kreatifitas Visual dan Verbal}

Banyak juga iklan yang muncul hanya memenuhi halaman majalah atau kuran namun tidak enak untuk dibaca atau diliat. Hal ini disebabkan oleh lemahnya kreatifitas visual atau teks yang dipakai. Iklan yang tayang di televisi juga mempunyai kasus yang sama, tidak semua iklan yang muncul memiliki stadarisasi kualitas image/visual. Misalnya resolusi yang rendah, format yang keliru, penempatan dan pemilihan media yang tidak sesui, semua mempengaruhi penampilan iklan. Kita memang tidak bisa memembendung keinginan para pengiklan untuk menawarkan produknya melalui media manapun. Namun iklan sering kali lagi-lagi menjadi materi yang akan semakin tidak dipedulikan lebih-lebih karena materinya yang minim kreatifitas.

Di sebuah majalah nasional seorang pembaca mengeluhkan di surat pembaca tentang banyaknya iklan "jelek" di majalah tersebut, sehingga artikel di rubrik-rubrik yang bagus tercemari oleh iklan-iklan yang asal tersebut.

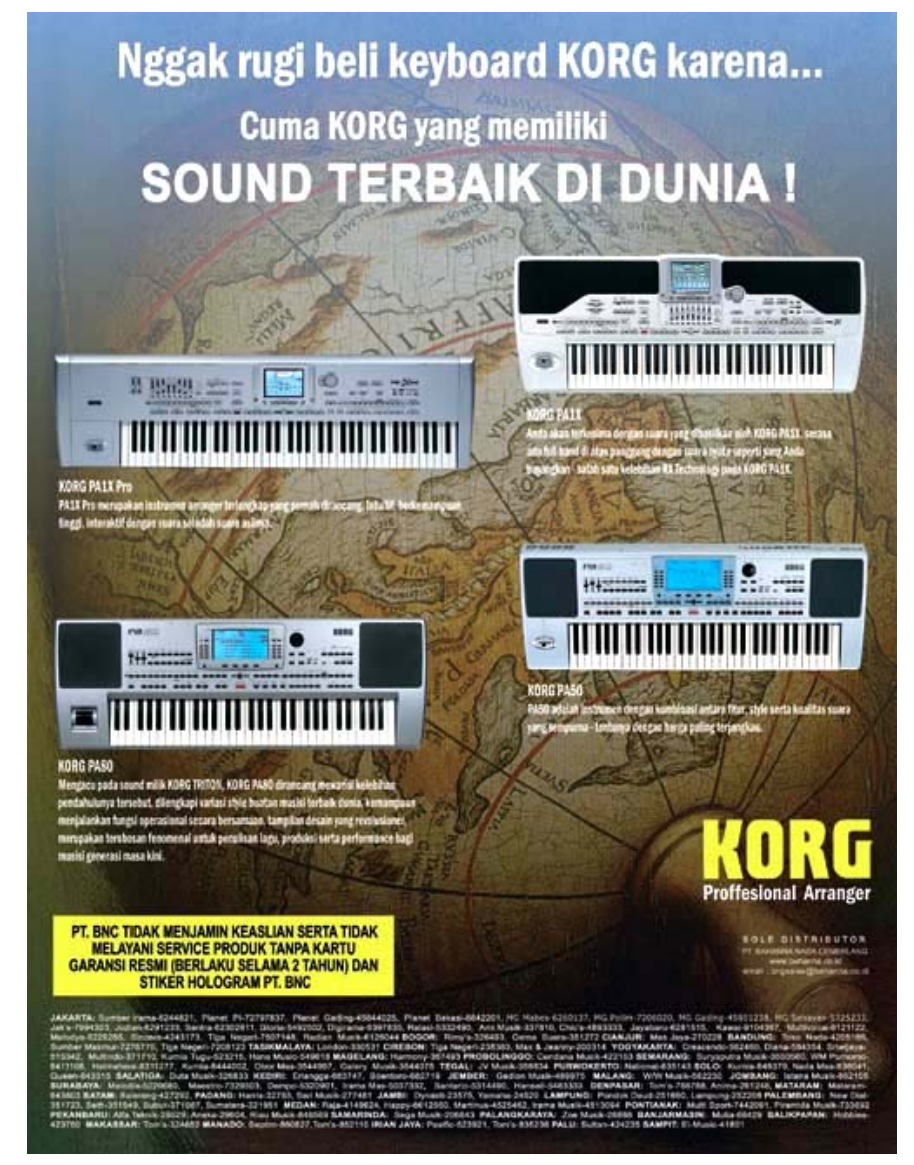

Gambar 9 Iklan tanpa Kreativitas

Menenggelamkan ekuitas produknya; iklan yang baik secara visual tentu saja akan lebih mudah ditangkap, karena komposisinya yang sudah diukur dengan penyuguhan terbaik untuk mata pembacanya. Pemilihan dan ukuran font juga sudah dipikirkan sedemikian rupa. Belum lagi bagaimana memilih kaliamat atau kata yang tepat untuk menyampaikan pesannya. Semua membutuhkan kreatifitas yang tinggi. 


\section{Beriklan bukanlah Investasi}

Bagi sebagian besar masyarakat kita beriklan merupakan kejadian yang sangat fantastik, banyak sekali rupiah untuk membiayai iklan. Pemahaman yang sering kali muncul adalah ukuran kesuksesan penjualan setelah beriklan apa? Jadi menghitung keuntungan beriklan masih dikaitkan seperti modal yang dipakai untuk produksi.

Pemahaman ini yang mempengaruhi pengiklan untuk membuat iklan hanya sekedarnya. Para pengiklan langsung datang ke tukang setting atau percetakan untuk membuatkan hajat iklannya, yang kita tahu sendiri tempat-tempat tersebut bukan tempat untuk menciptakan iklan. Alhasil banyak sekali iklan-iklan sampah yang sangat mengganggu keutuhan media cetak ataupun elektronik kita.

\section{Perlunya langkah-langkah untuk Menedukasi Pengiklan}

Keinginan untuk bisa menikmati dan melihat iklan-iklan cantik, cerdas dan komunikatif tentu saja bukan hanya lahir dari Persatuan Perusahaan Periklanan Indonesaia (PPPI), namun harus juga lahir dari tempat dimana akan dicetak calon-calon pencipta iklan yaitu di kampus. Penanaman pemahaman tentang kreatifitas iklan dengan sudut pandang yang komplit menjadi agenda wajib di tiap sesi perkuliahan periklanan. Di samping itu juga pemahaman di mana iklan bukan hanya diciptakan untuk mewakili hajat pengiklan saja namun juga harus bisa mengusung variabel moral dan pendidikan bagi penikmatnya. Hal inilah yang akhirnya akan kian menguatkan posisi tawar iklan.

\section{DAFTAR PUSTAKA}

Duncan, T. (2005). Principles of Advertising \& IMC. US: McGraw-Hill. 